\title{
13 Long-Distance Diffusion of Affinal Kinship Terms as Evidence of Late Holocene Change in Marriage Systems in Aboriginal Australia
}

\section{Introduction}

Ian Keen has made significant contributions to the comparison of Australian Aboriginal societies, and specifically to the relationship between types of marriage, kinship systems and other aspects of society and economy. He has maintained a commitment to the rigorous study of kinship systems and to comparative anthropology, or ethnology, when these orientations became unpopular in sociocultural anthropology. One of his major works (2004) systematically compared representative groups throughout Australia, emphasising how aspects of social organisation linked to economies. On a smaller scale was his brilliant study of how the scale of polygyny differed in two neighbouring areas of Arnhem Land, seeking the explanation in matrilateral cousin marriage and networks, age structures and economy (1982).

In recent times he has also joined forces with linguistics in investigating the prehistoric development of these relationships of kinship, marriage and other aspects of social organisation, in the AustKin project (Dousset et al. 2010). One study looked at how asymmetrical cross-cousin marriage developed, with 
crucial evidence supplied by the change in meaning of kinship terms. Notably the change in marriage type played a strong role in changing meanings of terms. The kinship terms in this case are inherited words within the Pama-Nyungan language family and its subgroups (McConvell and Keen 2011; Keen 2013b).

However, another striking phenomenon is the preponderance of affinal (in-law and spouse) terms among loanwords in kinship vocabulary. Consanguineal terms tend not to be borrowed widely unless they also function as affinal. Apart from affinal terms, kinship terms are rather rarely borrowed. ${ }^{1}$ Affinal terms, however, include some of the most long-distance travelling loanwords (Wanderwörter). Why is this so? One might readily guess that words related to marriage are among those that tend to be shared in wide areas since exogamous marriage between language groups is a most salient and frequently discussed topic. Further than this, though, it may be that these new words for spouses and in-laws were first introduced because they were key elements in new marriage practices that were diffusing. This opens a window on changes in the nature of societal and intersocietal alliance in the last few thousand years in the late Holocene in Australia.

In this chapter, two examples of such long-distance affinal kin loans are examined: ${ }^{2}$

1. A term ramparr, originally associated with mother-in-law and avoidance in the northeast Kimberley region, which diffused into the west Kimberley with a change of meaning to father-in-law, then (affected by sound change) spread east as lamparr(a) through the southern Kimberley into the Northern Territory. These changes appear to be associated with an increase in power of the father-in-law in the arrangement of marriage.

\footnotetext{
1 There are also cases of borrowing of consanguineal terms but they are rarer. One circumstance which can trigger this type of borrowing is a shift to a different type of kinship system (for instance from Kariera to Aranda), which requires additional terms that are imported from neighbouring languages, as in the case of borrowed 'father's father' terms in Ngumpin-Yapa (McConvell 1997a: 217-20). Arguably, this change is related to new marriage patterns between an incoming and a resident population, and is thus not totally divorced from the question of affinal networks being discussed for the diffusion of affinal terms in this paper. Some language families appear to have borrowed a wide range of kinship terms over a long period, like Nyulnyulan from Pama-Nyungan subgroups and other neighbours, discussed below in the section 'Mother-in-Law > Father-in-Law'. The pattern of these spreads is different from that of the Wanderwörter considered in this paper (cf. Haynie et al. 2014).

2 Space does not permit consideration of other examples, such as (a) the term ngumparna ('husband'), found throughout the Ngumpin-Yapa subgroup, but also in neighbouring areas and some distance away in Arnhem Land; and (b) the term nyupa (also ngupa, nyuwa, etc.), found in a very wide area of Pama-Nyungan across Australia mainly with the meaning 'spouse'. These require detailed analysis to determine to what extent they are inherited in Pama-Nyungan subgroups (or for (b), within Pama-Nyungan as a whole). (b) may be inherited in Pama-Nyungan, or partly or mostly diffused at an early stage in the development of the PamaNyungan family. If the latter is the case, then this is one of the most widespread ancient Wanderwörter in Australia, with the most central meaning of 'spouse' from the start, or very soon after the start.
} 
2. A term tyamVny (where $\mathrm{V}$ stands for an indeterminate vowel), which is quite widespread as an inherited term for 'mother's father' in Pama-Nyungan, that also diffused quite virulently into non-Pama-Nyungan languages in the north Kimberley and Arnhem Land. While the core meaning does not appear to be affinal, the mother's father term is frequently also used to mean 'cross-cousin' and then 'spouse' where cross-cousin marriage is practised.

(1) is clearly a Wanderwort from early on in its career, and spread across an area of northern Australia. (2) only became a Wanderwort as a late departure, when it acquired a new function and started to be borrowed into non-Pama-Nyungan families.

These studies point towards possible generalisations relevant not just to Indigenous Australia but to population dynamics, and its relation to kinship terminology systems and their distribution, more generally. They link to work on the study of exogamous marriage and in-law chains between language groups in Indigenous Australia, and beyond (Denham 2013), adding to the themes and discoveries in Ian Keen's work.

\section{Inheritance and Diffusion of Kinship Terms}

It has been remarked for several language families that kinship terms are highly stable over long periods. This is generally because they are inherited from the proto-language without replacement. This is true for instance of Indo-European, where of a sample of 36 terms (six kintypes in six branches) reconstructed to proto-Indo-European some 6,000-7,000 years ago, 27 (75 per cent) are retained in the daughter subgroups and only nine (25 per cent) replaced (Clackson 2007: 207). These rates of retention are considerably higher than those predicted by the loss of 14 per cent of basic vocabulary items per millennium proposed in glottochronology.

There are differences in the stability of terms, which seem to have some correlations with the meanings of terms. The most stable appear to be the core consanguineal terms (such as 'mother','father', 'brother', etc.), whereas collateral terms ('uncle', 'aunt', 'cousin', etc.) and affinal terms (spouse and inlaw) are less so, not only in Indo-European but also in other families (Matras 2009: 169-72). ${ }^{3}$

3 This does not mean that collateral and affinal terms are not stable, just that they tend to be less so. Marck et al. (2011) argue that terms for cross-cousin (collateral, and affinal because of cross-cousin marriage) are stable and inherited in East Bantu. 
Those terms which are not inherited (and therefore not stable) can be either loanwords or coined from other resources in the language. For instance, regarding coinages, 'husband' can be the word for 'man' and 'wife' the word for 'woman' as in a number of Indo-European languages - and the spouse terms have this kind of origin in some Australian Aboriginal languages. I focus here not on this kind of process but on the diffusion of kinship loanwords.

The borrowing, often widespread borrowing as Wanderwörter, of affinal terms has been noted for instance by Dixon and Aikhenvald (1999: 8) for 'mother's brother'/ 'father-in-law' kuku or koko in Amazonia, and we will be seeing this kind of situation echoed in our Australian examples. Tuite and Schulze (1998) cite this as a parallel example to the borrowing of the Indo-European term for 'daughter-in-law' ( ${ }^{*}$ snus) into a large number of Caucasian languages (cf. Matasović 2012). In both cases, they claim, avoidance between in-laws motivated the replacement of original inherited terms by loans - the Amazonian case between a father-in-law and daughter-in-law, and in the Caucasus the ambivalent and often negative treatment of wives taken into the husband's lineage and community. ${ }^{4}$ This importance given to avoidance seems to constitute a distinct general hypothesis about why some affinal terms diffuse so widely. While avoidance also comes into our stories of affinal term diffusion in Australia, it is doubtful if its role is primary: we return to this topic later in this chapter.

In Australia, kinship terms in general also seem to be quite stable, but some affinal terms are labile due to their propensity to be borrowed. In the very widespread Pama-Nyungan language family it has been possible to reconstruct a significant proportion of kin terms with some confidence (e.g. McConvell 2008, 2009). This contrasts with other semantic fields where the proportion of reconstructible roots is much lower. Narrowing to a smaller range, within the Ngumpin-Yapa subgroup of Pama-Nyungan, spoken in the Tanami Desert and Victoria River district of the Northern Territory and the South Kimberley of Western Australia, the majority of kinship term roots are retained and can be reconstructed. They are replaced in a number of cases by loanwords whose origin can be traced. The loanwords include several with affinal meanings, for instance in Gurindji ngumparna ('husband; husband's brother') and lamparra ('fatherin-law, and reciprocally child-in-law'), the latter discussed in this chapter. The cognates of the proto-Pama-Nyungan term *tya $(m)(p) i$ 'mother's father' (tyamirdi, tyawityi, etc.) are primarily not affinal in this language subgroup, but in this chapter it is illustrated how their extended affinal functions (as spouse, siblingin-law) elsewhere contribute to their diffusion. There are also consanguineal loanwords mentioned in note 2 .

4 Dziebel (2012) claims that marriage exchange existed between speakers of Indo-European and North Caucasian languages and adduces genetic evidence. 
In the following sections, the examples of the two affinal Wanderwörter to be discussed are introduced in turn. Maps are provided for each example showing their diffusion paths, and where relevant, changes in their meaning.

\section{Ramparr > Lamparr: 'Mother-in-Law > Father-in-Law'}

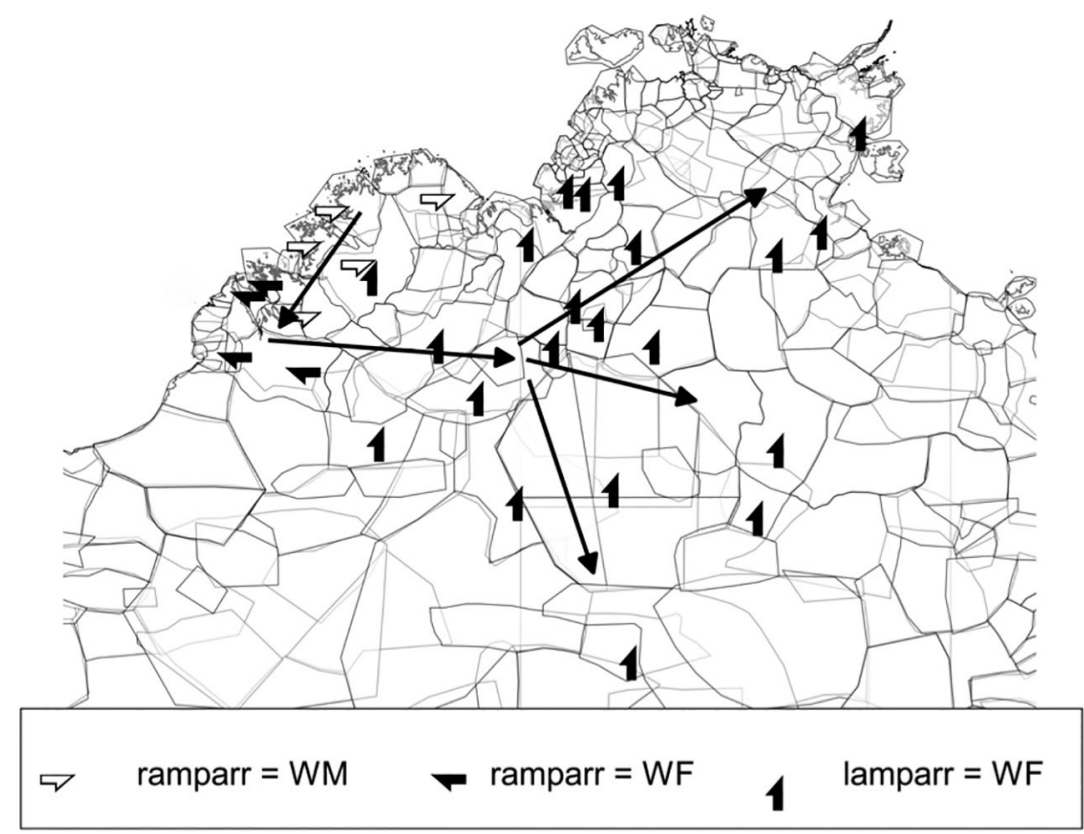

Figure 13.1 Spread of ramparr/lamparr(a). ${ }^{5}$

Source: Patrick McConvell.

Here the stages of diffusion are dealt with in summary in reverse chronological order, starting with Stage 5 and going back to the origin, Stages 0-1. This labelling is also used in Figure 13.1. The following sections go into more detail about the loans, meaning changes and probable socio-historical contexts. 


\section{Stage 5: The Recent Eastward Diffusion in the Eastern Northern Territory}

The term lamparra is widespread across a swathe of the Northern Territory from the Victoria River District east into the northern part of Central Australia and central Arnhem Land. It has the primary meaning of a man's wife's father, and reciprocally also of a man's daughter's husband, but also covering husband's father and reciprocal woman's son's wife in a number of groups. Throughout this region the term and associated practice (see below) are acknowledged by Aboriginal people to be a recent innovation arriving from the west within the last 100-150 years. For some languages the term is ascribed to Pidgin or Kriol, a lingua franca which spread in the same time period (e.g. Heath 1981: 109-10). In Figure 13.1 the stage of diffusion through the southern Kimberley is called Stage 4, and the mainly twentieth-century diffusion east of Mudburra Stage 5.

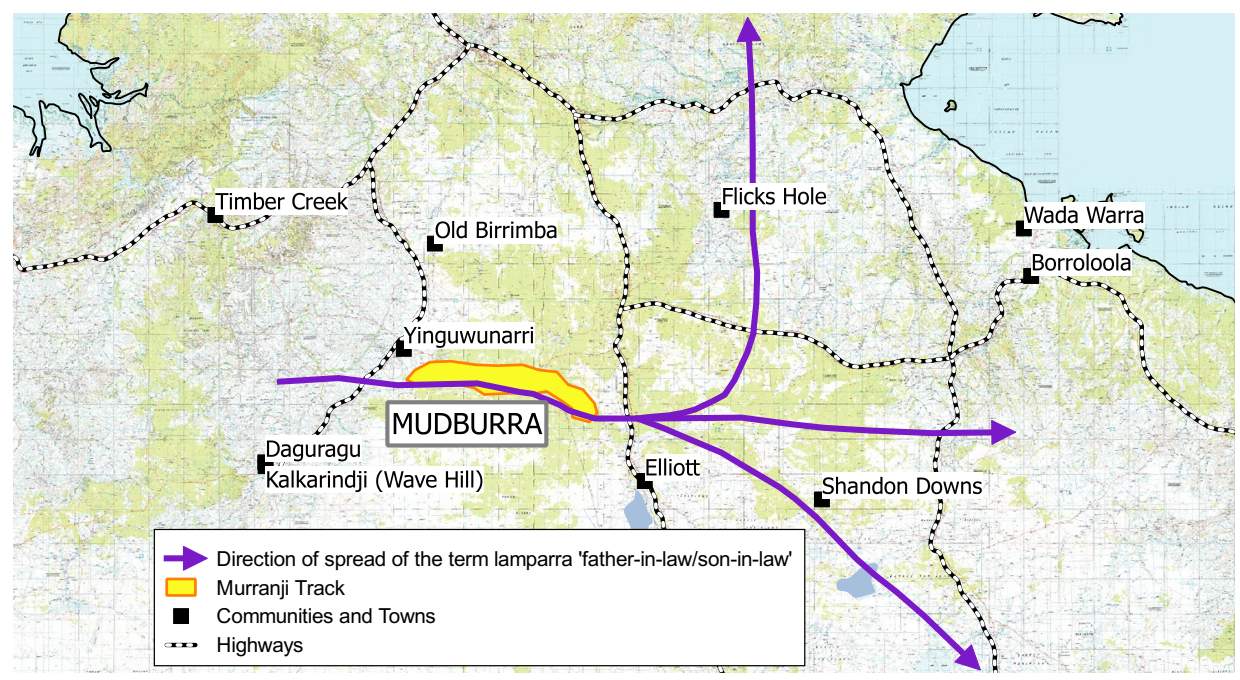

Figure 13.2 Recent eastward diffusion in the eastern Northern Territory. Source: Patrick McConvell.

The form in the western Ngumpin language Walmajarri is lamparr, without the final vowel $-a$. The addition of a final $-a$ on consonant-final nouns is a regular sound change only in the most easterly of the eastern Ngumpin languages, Mudburra (McConvell 2009: 800, 803). The fact that further diffusion (Stage 5) to the east (and also back into Gurindji (Meakins et al. 2013: 200), and partially Jaru) is of the form with a final $-a$ indicates that the root passed through Mudburra on its journey. Mudburra was the language of the Murranji Track (Stock Route), heading east from Top Springs, along which drovers and their Aboriginal 'stockboys' took cattle in large numbers beginning in the 1880s 
(Lewis 2007). This is, no doubt, the channel of communication through which the Mudburra term was carried to Aboriginal people being linked up by the new cattle industry.

\section{Stage 4: The Diffusion from Southern Nyulnyulan in the Western Kimberley into and through the Ngumpin Languages of the Kimberley and Victoria River District of the Northern Territory}

Less well known is the earlier history of diffusion of the term. The immediate source of the term lamparr 'wife's father' in the Central Kimberleys PamaNyungan (Ngumpin-Yapa) languages is the adjacent Nyulnyulan (non-PamaNyungan) language family of the west Kimberley, where the term is ramparr. The meaning of the term is also 'wife's father' in some Nyulnyulan languages and, particularly significantly, in the easternmost language Nyikina which is in contact with the western Ngumpin-Yapa languages (for earlier meanings in northern Nyulnyulan and Worrorran, see below).

As with the addition of $-a$ in Mudburra, here again the change in sound-from initial $r$ to initial $l$-is highly significant for tracing the history of diffusion of the term. The regular sound change of lateralisation $(r>r l$, a retroflex l, written $l$ at the beginning of the word) has been identified as one of the common innovations which serve to define the Ngumpin-Yapa subgroup, to which both Mudburra and Walmajarri and several languages in-between belong (McConvell and Laughren 2004). This change $r>r l$ must then have happened roughly at the proto-Ngumpin-Yapa language stage, around the time before Ngumpin-Yapa differentiated into several distinct languages. Using archaeology to calibrate (McConvell and Smith 2003) this era can roughly be dated at around 3,0002,500 years ago, in the first millennium BC. The word ramparr must have entered the proto-Ngumpin-Yapa language before this sound change stopped operating, approximately at the same period, so the change applied, yielding lamparr.

\section{Stages 3 and 2: From Worrorran to Western Nyulnyulan and Eastern Nyulnyulan}

Going one stage further back into the history of ramparr, we find its source to the northwest of the Nyulnyulan languages, in the Worrorran language family in the north Kimberley. The diffusion from Worrorran into Nyulnyulan labelled Stage 3, does not involve any change in form of ramparr but does involve a major 
change in its meaning, from 'wife's mother' and 'wife's mother's brother' in some languages to 'wife's father'. This is discussed further below, in the section 'The Wider System Context of Change in Meaning of Ramparr/Lamparr' ${ }^{6}$

The absence of a change in the sounds of the word makes it difficult to attempt any chronology for this diffusion in the same way as for Stages 4 and 5. Clearly, though, if Stage 4 is placed at 2,500-3,000 years ago, Stages 2-3 must have preceded that period.

In Stage 2, which preceded Stage 3, ramparr diffused west from western Worrorran to western Nyulnyulan. The form remained the same and its meaning remained focally the same, at least in Bardi, but the gender was restricted to the brother of wife's mother, not WM herself (Aklif 1999: 119). The shift to WF began to occur in Stage 3 as the term travelled southwest to western Nyulnyulan, and more completely as it went into eastern Nyulnyulan and reached the eastern boundary of the family, in Nyikina.

\section{Stages 1 and 0: Meaning Change between Eastern and Western Worrorran: Barrier > Avoidance Relations > Mother-in-Law}

There is an evolution of meaning from an original more concrete meaning of 'screen' or 'barrier' to 'avoidance kin relations' in general in northeastern Worrorran. This is labelled Stage 0. Further west in Worrorran, closer to the zone of contact with Nyulnyulan, the meaning of ramparr becomes focused on the mother-in-law (wife's mother) specifically-Stage 1, and that is the meaning that is diffused farther west in Stage 2.

Avoidance of 'taboo' in-laws is symbolised and actualised by barriers, which include physical screening with some object or the hands over the face (referred to by Coate and Elkin (1974) as the 'rambar wall'), as well as metaphorical usage, referring to the ban on looking at or talking to the avoidance in-law. Vocabularies of the eastern Worrorran languages in particular emphasise the physical barrier sense, including 'windbreak'; so, based on the general principle that concrete senses are earlier, the direction of change is likely to have been from 'barrier' of a general physical kind to the class of relations who are avoided. In Ngarinyin (Coate and Elkin 1974 (Volume 2): 448-9), a verb derived from this root has both senses, illustrating the stage of transitional polysemy:

\footnotetext{
6 Stokes and McGregor (2003: 66) reconstruct a term "rambarr to proto-Nyulnyulan in the meaning 'male parent-in-law: HF' — but with a query beside WF. See below for further discussion. Bowern (2007) has proposed that the development of the western branch was driven by a movement of people from the coast to the Fitzroy River Valley in the inland, with changes of meaning of lexical items accompanying this.
} 
rambara bijorengka

1. they screened themselves;

2. they became in-laws.

The second main sense of ramparr in northeastern Worrorran (Drysdale and Forrest Rivers) is the avoidance relationship itself and the relations who fall under this rule. Hernandez (1941: 227) states that it would be more correct to say that rambar is not a kinship term but only a taboo existing between certain relations'. Ramparr are primarily 'a man and his actual, future or possible mother-in-law, and her brothers'.

This origin gives some insight into the self-reciprocal nature of the suite of ramparr/lamparr terms in many of the languages, referring not just to the member who 'promises' a wife, but also the one who receives her, the son-inlaw. In relation to the western Worrorran language, Worrorra, the dictionary (Clendon 2000: 56; Clendon 2014: 462) gives the following definition:

rambarr mana (noun): the set of avoidance-category kin who are related to you as wife-givers; includes kurruma, kurrumaanya, ngalinjaaya, jalinjaanya, walbaya and walbayinya ... DaHu-WiMo pairs are walbaya and kurrumaanya to each other respectively, and constitute the strongest form of the rambarr relationship category.

This definition encompassing a broad category of 'wife-givers' links back to the common feature of avoidance involved.

This notion of 'wife-giver' thus refers to a group of people. What becomes important as we look into the transformations of meaning of this term in its etymological history is who exactly has the main say over the bestowal of a woman in marriage. This is taken up in the next section, 'Mother-in-Law > Father-in-Law'.

In the whole region we have been speaking of, the most severe avoidance is practised with a man's mother-in-law. Of course, we should not assume that this was the case going back several thousand years, and elsewhere in Australia other affines such as siblings-in-law are equally or more subject to verbal and physical avoidance. There appear to have been two types of meaning of the term in Worrorran: a general term for avoidance relations, and primarily 'wife's mother'. These two meanings are distributed across the different languages in such a way that we cannot be sure if they represent two chronological stages. Unlike in the other later phases of the movement of this word which have been 
discussed, in this earliest phase, we do not know that these two meanings are linked by diffusion of the word: the term may be inherited from the protolanguage with a complex meaning change in the western branch. ${ }^{7}$

As ramparr diffused into western Nyulnyulan (e.g. Nyulnyul and Bardi (Elkin 1932; Aklif 1999)) its meaning shifted from a group of people focused on wife's mother, to wife's mother's brother. In both cases the meaning included the reciprocal; man's sister's son's wife in Worrorran and sister's daughter's husband in western Nyulnyulan. In Worrorran, e.g. Ngarinyin (Elkin 1932: 317-9), it is reported that rights of bestowal in marriage rest with the wife's mother's brother, and the same is reported for Nyulnyul (Elkin 1928; Scheffler 1978: 179, 190). It seems likely that the actual wielder of the power of making the contractual decision with another group became the focus of the meaning in the new situation.

\section{Mother-in-Law > Father-in-Law}

The shift of meaning of ramparr from the group and the mother of the bride to the actual bestower, the wife's mother's brother, in the above diffusion from Worrorran to Nyulnyulan, sets the stage for the more dramatic change of meaning to father-in-law, as greater power over bestowal was transferred to him in eastern Nyulnyulan, e.g. Nyikina and Yawuru. ${ }^{8}$ It is probable that the eastern Nyulnyulan speakers expanded into the hinterland (Bowern 2007), and that the migrants were 'moving in on' groups of people already resident in the area. ${ }^{9}$

The most problematic part of the history of ramparr is the change of the term from mother-in-law and her brother in western Worrorran and eastern Nyulnyulan to father-in-law in eastern Nyulnyulan. While these meanings both refer to parents-in-law, the change from WM(B) to WF is unexpected. Significantly, a change from mother-in-law to father-in-law apparently represents a contravention of a principle of semantic change set forth by Evans and Wilkins (2000) that I further developed in relation to kinship terms

\footnotetext{
$7 \quad$ Worrorran is analysed as having three branches in McGregor and Rumsey (2009). As we have moved two steps backwards in time from stage 3,000-2,500 BP, it is possible that the origin of ramparr in the North Kimberley was 4,000-5,000 years ago or more. This could be compatible with it being in the proto-language as Worrorran has significant internal divergence, but at that time ramparr may not have had the connotations of affinal avoidance, and subsequently 'mother-in-law' until some time later, perhaps 4,000-3,500 years ago. These dates need confirmation, but there is a good chance of the linguistic stratigraphy and chronology improving in the coming years, and archaeology, rock-art and plant and human genetics being brought into the picture, to provide calibration (McConvell, Saunders and Spronck 2014; Rangan et al. 2015).

8 The 'wife's father' meaning is also recorded for Jawi which is centred around the islands of Northern Dampier Peninsula, and is a western Nyulnulan language closely related to Bardi.

9 This is the type of language expansion which I have called 'downstream spread' (McConvell 2010). This name can be confusing: in this case as the spread in this case is geographically upstream, so I suggest 'encroaching spread' as a better term. I have suggested that this form of expansion is related to particular types of kinship system, specifically Omaha skewing, which supports linguistic exogamy (McConvell 2012).
} 
(McConvell 2013: 194-6). According to this hypothesis, a change from sense A to sense B passes through a stage of polysemy in which the term has both senses $\mathrm{A}$ and $\mathrm{B}$, and that such a transitional polysemy should be evident in historical sequences, or contemporaneously elsewhere, and specifically in the region where the change is being proposed. While many changes in kinship term meanings do show these properties of transitional polysemy in Australia, there is doubt about where mother-in-law and father-in-law share the same term anywhere, even in any of the Kimberley languages under discussion.

However, in this case, as we have noted, in its early history the term ramparr has a wider meaning of an avoidance relationship which encompasses several types of in-laws who may also be designated by more specific kinship terms. This may be, then, a case of a term in which there is what we might call hypopolysemy - that is, one of two meanings involved is broader and includes the other, narrower, meaning. This is common as a synchronic pattern in fauna terms in Australia and also explains semantic shift from generic term for a life form to a species term or vice versa (McConvell 1997b). ${ }^{10}$

There is at least one more fairly clear case in Australian kinship where a similar change has happened. In Cape York Peninsula (Paman subgroup of PamaNyungan) the term *mukVr means 'mother's brother', ${ }^{11}$ but in the rest of the country where cognates of the term are found (mainly in Pama-Nyungan) it means 'father's sister and/or wife's mother'. Where the primary meanings of the terms seem to be consanguineal, they also both have affinal senses deriving from the rules of marriage: the equation $\mathrm{FZ}=\mathrm{WM}$ is quite widely distributed in Australia, especially where there is or was a Kariera system and cross-cousin marriage. The common ground between $\mathrm{MB}(\mathrm{WF})$ and FZ (WM) could be their key role as decision-makers about their daughter's marriage. ${ }^{12}$

Ian Keen (2013b) has helped us on the road to solving this puzzle by pointing out the similarities and differences between the Yolngu and some eastern Cape York Peninsula groups, on the one hand, and the northern Kimberley groups, on the other. Both of these areas have a central area of asymmetrical matrilateral marriage and kinship, bracketed by areas of symmetrical (Kariera) marriage and kinship to the east and west. In the case of CYP-Yolngu, it can be proposed

10 The term 'hyperpolysemy' has already been claimed by Evans (1992) to mean something quite different. 11 In a number of Paman languages reflexes of 'mukr have the meaning 'mother's elder brother', with a distinct term for mother's younger brother. In eastern CYP what McConnel (1950) called 'junior marriage' is practised: a man should marry his MyBD, and a woman her MeBS. A mukr is therefore a woman's husband's father in this area.

12 The same is true of the change in the meaning of the term ramparr between WM in Worrorran and western Nyulnyulan and WF in western Nyulnyulan, where the direction of change is the opposite to that between Cape York Peninsula and the Yolngu of Arnhem Land. Note however that the term *mukr is a proto-Pama-Nyungan term which is inherited, and the change of meaning occurs as part of this inheritance. Ramparr/lamparr, on the other hand, is a Wanderwort, a widespread loanword. 
that the initial state was that found in the east, of a symmetrical Kariera system which gave way to an asymmetrical matrilateral system in the west. In the original system, the term *mukr was 'mother's brother/wife's father', but in the changed western Yolngu system it became 'father's sister/wife's mother'.

In the case of the north Kimberley, the central area is dominated by an asymmetrical (matrilateral) system of marriage and kinship, with however more Kariera symmetrical features in the northeast Worrorran languages which, according to Keen (2013b: 144) may be a forerunner of the Ngarinyin (asymmetrical) type. In the central south among the Ngarinyin, 'the marriage system ... comes to resemble the Yolngu asymmetry of exchange between groups' (ibid.: 142). The asymmetrical system gives way to a symmetrical system in the south-west (ibid.: 141), that is, in the Nyulnyulan area. ${ }^{13}$

There is, then, a contrast between marriage arrangements in the Worrorran and Nyulnyulan groups which could affect how the affinal terms are interpreted. In western Worrorran ramparr designates 'wife-givers', associated with unilateral alliance of wife-giver clans and wife-taker clans, whereas the Nyulnyulan marriage system is primarily bilateral. This reciprocality of ramparr/lamparr referring to both parent-in-law and child-in-law is a feature of the Nyulnyulan, Ngumpin-Yapa and other groups to the east.

The broadest definitions of ramparr encompass a wide grouping of 'wife-givers', but even where this is narrowed down to specific affines there is ambiguity of the 'wife-giver', between the wife's mother who is subject to the most stringent avoidance and the wife's father who 'actually promises' the bride. This ambiguity provides the seeds of the split in ramparr between the meaning WM(B) and the meaning WF which becomes dominant in the eastward diffusion.

Elkin, writing of the Ungarinyin (Ngarinyin, a southern Worrorran group), addresses this ambiguity, although the term ramparr is not mentioned:

The possible wife must be the daughter of a woman who is a 'proper' mother-inlaw, that is, she must belong to a horde [clan] which is wolmingi, wife's mother, to him [the husband] while the actual promising of the bride is done by her [the mother-in-law's] husband, ego's waiingi. (Elkin 1932: 314)

13 Just southwest of the Nyulnyulan languages is another unrelated language, Karajarri of the Pama-Nyungan Marrngu subgroup, whose system has been interpreted as asymmetrical, and whose name ('Karadjeri') was chosen by Elkin to designate asymmetrical systems (Scheffler 1978: 208). Scheffler (ibid.: 219) disputes that this is a true 'asymmetrical' system. 


\section{The Wider System Context of the Change in Meaning of Ramparr/Lamparr}

The kinship systems of the Nyulnyulan family such as Nyulnyul have been described by Elkin as Aranda, because of a preference for MMBDD marriage and prohibition on cross-cousin marriage. Scheffler (1978: 173), however, believes that they are fundamentally Kariera. Certainly some features of the Nyulnyulan systems do look more 'Aranda'-having four distinct grandparent terms for instance, illustrated in Table 13.1 for Nyulnyul.

Table 13.1 Grandparental loanwords from Marrngu in Nyulnyulan.

\begin{tabular}{|l|l|l|l|l|l|}
\hline Kintype & Elkin & McGregor & $\begin{array}{l}\text { Additional } \\
\text { senses }\end{array}$ & Reconstruction & $\begin{array}{l}\text { Related K - Karajarri; } \\
\text { M - Mangarla }\end{array}$ \\
\hline FF & kalod & kalud, kalurd & mSC & *kalurtu & kalurtu (K) \\
\hline FM & kabil & kabirl & fSC & *kaparli & kaparli \\
\hline MM & kamad & kamard & & *kamirta & kami \\
\hline MF & djam & tyam & & *tyamu(ny) & jampartu, jamu (M) \\
\hline
\end{tabular}

The presence of four distinct grandparent terms is often considered a criterion of the Aranda system (but see Keen 2013a for a reformulation of the typology of Australian Aboriginal kinship systems). However, the approach being taken in this paper is diachronic, so it is necessary to consider not just the patterns of the current configurations of kinship terms, but where they came from and when. A glance at the table is enough to raise suspicions that all these Nyulnyulan terms are loanwords from the nearby Marrngu subgroup of Pama-Nyungan.

The Nyulnyulan kinship terminologies constitute one of the rare exceptions to the principle enunciated at the beginning of this chapter, that kinship terms are mainly inherited, not borrowed. The grandparental terms in Table 13.1, and a number of other kinship terms, appear to have been borrowed wholesale from a neighbouring group in the Marrngu subgroup of Pama-Nyungan, which is only very distantly related linguo-genetically. The motivation for this mass borrowing clearly goes far beyond filling gaps in a system. ${ }^{14}$

14 While there are a few inherited Nyulnyulan kinship terms still present, the historical change here is close to a complete takeover of both kinship systems and terminology from Marrngu. A full investigation of this cannot be carried out in this chapter. For instance, the changes in the second vowel of the MM and FM terms are regular and constitute evidence that the loans belongs to an older stratum, which may be datable. The hypothesised movement of Nyulnyulan speakers south and east would not necessarily provide the answer, since while the eastern Nyulnyulan languages may be more affected, the whole family has this kind of profile, pointing perhaps to this transformation being early in the history of the family. There are a fair number of other apparent early loans from Pama-Nyungan into Nyulnyulan, apart from in the kinship domain, perhaps indicating early contact with Pama-Nyungan. The dominance of Pama-Nyungan in the kinship system may have resulted from heavy intermarriage between the two groups with concomitant adoption of the Pama-Nyungan terminology. Nyulnyulan languages also adopted the section system from the west and this may have been the occasion of some assimilation of the kinship terminology to that of the Pama-Nyungan. However, section systems have diffused in many parts of Australia without causing this kind of unusual radical diffusion of kinship terminology. 
Beyond this there is a kinship loanword in the affinal (in-law) category, from the opposite direction, Worrorran in the northeast, which we have introduced: ramparr.

Table 13.2 shows the changes of meaning of ramparr/lamparr and several other affinal terms of the +1 and -1 generations as they diffuse from Worrorran, to Nyulnyulan, then to Ngumpin (Pama-Nyungan).

The term ramparr begins in northeast Worrorran with a focus on WM although it has a wider 'barrier' and 'avoidance relations' meaning too. In western Worrorran the term also has a wide 'avoidance' meaning but retains a focus on mother-in-law, WM. As the term moves into Nyulnyulan the situation becomes more complex. There is a shift of focal meaning from mother-in-law to her brother, WMB. In Jawi in the northern islands, however, the meaning changes to father-in-law (WF).

In Nyulnyulan other affinal terms come into play affecting the distribution of senses. Rangin/rangan, which appears to be an inherited Nyulnyulan term, rather than a loan, covers a range of affinal +1 and -1 kin types in western Nyulnyulan, but not including WM, or WMB. These latter are respectively yalirr in Nyulnyul and a cognate in Bardi, and probably inherited; and ramparr.

While WF is ramparr in Jawi and rangin can have WF as one of its meanings in other western Nyulnyulan languages, there is another expression which is also WF in all the Nyulnyulan languages. Its full form is kaka tyami-nyarri, literally 'mother's brother $(k a k a)$ associated with mother's father (tyami/u)', but commonly only the second word is used. There is commonly an equation (polysemy) between the MB term and WF especially in groups with Kariera systems, where the mother's brother gives his (classificatory) daughter to her cross-cousin in marriage. The father-in-law relationship is usually not an actual genealogical close relationship, so to distinguish clearly the affinal relationship from the consanguineal uncle the qualification is added. This is a little puzzling as the consanguineal 'mother's brother' also has a consanguineal relationship to 'mother's father', literally speaking. However the term for MF is often equated with cross-cousin by alternate generation equivalence and then the cross-cousin has a connotation of marriage - spouse or sibling-in-law. This will be explored further in the second case in this chapter about the history of the term *tyam ( $p$ ) $V$. So in fact this expression connotes 'MB associated with marriage partners', i.e. father-in-law. 
Table 13.2 Diffusion and change of meaning of affinal terms from north to west to southeast Kimberley.

\begin{tabular}{|c|c|c|c|c|c|}
\hline & E. WORR. & W. WORR. & W. NYNY. & E. NYNY. & W. NGUMPIN \\
\hline \multirow[t]{3}{*}{ ramparr } & \multirow[t]{2}{*}{ WM } & \multirow{2}{*}{$\begin{array}{l}\text { Wife-givers } \\
\text { (Worrorra) }\end{array}$} & WMB & WMB & \multirow{3}{*}{ >lamparr } \\
\hline & & & WF (Jawi) & WF (Nyikina) & \\
\hline & ZSW & $\begin{array}{l}\text { WM (Ngarinyin, } \\
\text { Unggumi) }\end{array}$ & $\mathrm{ZDH}$ & $\mathrm{fDH}$ & \\
\hline \multirow[t]{4}{*}{ lamparr } & \multirow[t]{4}{*}{$x$} & \multirow[t]{4}{*}{$x$} & \multirow[t]{4}{*}{$x$} & \multirow[t]{4}{*}{$\mathrm{HF}$} & WF \\
\hline & & & & & $\mathrm{HF}$ \\
\hline & & & & & SW \\
\hline & & & & & $\mathrm{DH}$ \\
\hline \multirow{5}{*}{$\begin{array}{l}\text { rangin/ } \\
\text { rangan }\end{array}$} & \multirow[t]{5}{*}{$x$} & \multirow[t]{5}{*}{$x$} & SW & HM (Nyikina) & \multirow{10}{*}{$\begin{array}{l}\text { MARRNGU } \\
\text { Karajarri: WM }\end{array}$} \\
\hline & & & WF & BSW (Yawuru) & \\
\hline & & & $\mathrm{DH}$ & & \\
\hline & & & $\mathrm{HM}$ & & \\
\hline & & & $\mathrm{HF}$ & & \\
\hline \multirow[t]{2}{*}{ yalirr } & & & WM & & \\
\hline & & & $\mathrm{fDH}$ & & \\
\hline \multirow{2}{*}{$\begin{array}{l}\text { (kaka) tyaminyirr/ } \\
\text { tyaminyarri }\end{array}$} & & & \multirow[t]{2}{*}{ WF } & WF & \\
\hline & & & & $\mathrm{fDH}$ & \\
\hline \multirow[t]{2}{*}{ tyikal } & & & & WM & \\
\hline & & & & $\mathrm{fDH}$ & \\
\hline
\end{tabular}

As we move to the next step in the changes in the system, in eastern Nyulnyulan, we see that, for ramparr, the focal meaning of WMB is retained in Yawuru near Broome, but shifts decisively to WF in Nyikina upstream in the Fitzroy basin, with overlap persisting with kaka tyaminyarri. The term rangin loses several of the senses it had in the western branch, including WF, and is narrowed to HM in Yawuru and its near reciprocal BSW in Nyikina. A new term comes in for WM, tyikal, an innovation in this branch of Nyulnyulan, perhaps a loan from Karajarri tyikari WM. The direction could be the opposite, like rangin 'WM' which was clearly loaned from Nyulnyulan into Karajarri, although WM is not among the senses recorded for Nyulnyulan.

The term lamparru is borrowed back as a doublet from a later form in Walmajarri lamparr into western Nyulnyulan in the meaning 'husband's father' with an added $-u$ due to it passing through Bunuba, which has this addition as a regular sound change (see note 16). This is just one of the senses of the term in Walmajarri. Perhaps the meaning was narrowed in the process of borrowing, 
because the other main meaning 'wife's father' is already covered by kaka tyaminyarri, and ramparr in Nyikina (cf. McConvell and Ponsonnet 2013 on semantic narrowing in borrowing).

Nyikina was in contact with languages in the south-central Kimberley such as the most western language in the Ngumpin-Yapa subgroup, Walmajarri. Nyikina had probably been moving southeast for some time (Bowern 2007 ${ }^{15}$ ) with increasing interaction with Ngumpin languages, particularly Walmajarri, that was also moving north from the desert.

When the term ramparr was borrowed into Walmajarri the sound change of lateralisation * $r>$ rl was still in progress (McConvell and Laughren 2004), yielding lamparr (the initial $l$ is retroflex but not written $r$ in this position). This provides a time frame for this stage in the diffusion of this word, using calibration from a word for 'muller' (top grindstone; McConvell and Smith 2003). While this chronological aspect is not fully argued here, I estimate this loan of the word into Ngumpin with the lateralisation sound change as having occurred 2,500-3,000 years ago (but see note 15).

This phase of diffusion was significant not just because of a sound change but also because of a meaning change. The form ramparr had either the meaning 'wife's father' or 'husband's father' and reciprocals in some previous stages of diffusion but only partially, with overlaps from other terms and only in some languages. In the diffusion of lamparr to Ngumpin, though, all the meanings of WF and HF and reciprocals are combined. This coherent package diffused to the east over the next period, culminating in a rapid and virulent diffusion in the twentieth century, combined with and strengthened by a suite of cultural practices.

At bottom, the innovation was the recognition of the father-in-law as the prime wife-giver rather than the mother-in-law or her brother. This was supported by a new kind of interaction between the wife-giver and wife-taker which was no longer based on avoidance but on its opposite, a joking relationship. The unity of this relationship was enhanced by the fact that the two parties to the

15 Bowern (2007: 51) writes 'we might draw the tentative conclusion that speakers of eastern Nyulnyulan languages spread into an area already inhabited by speakers of Pama-Nyungan languages, and when they moved inland they encountered a new environment and borrowed the names for many new species from the previous inhabitants ... Although more evidence is required, the distribution of loans is suggestive of a migration East and inland from the Dampier peninsula, rather than the reverse'. Bowern describes the degree of divergence within Nyulnyulan as not great, perhaps about that of Romance - the group of languages descended from Latin, such as French, Italian, etc. One might conjecture based on this parallelism that the age of the family is around 2,000 years, and the spread of eastern Nyulnyulan inland between 2,000 and 1,000 years ago. This raises a problem for the chronology outlined for the lateralisation of $\mathrm{r}$ in proto-NgumpinYapa based on archaeolinguistic stratigraphy of 3,000-2,500 BP, if the term ramparr was borrowed from eastern Nyulnyulan when it contacted western Ngumpin, as lamparr. However an alternative could be that lateralisation continued to operate for a longer time until, say, between 2,000 and 1,000 years ago. 
marriage arrangement and the joking arrangement, the father-in-law and childin-law, were called by the same term, unlike for instance in languages where the father-in-law is called 'uncle' (MB) and the junior reciprocal is the nephew/ niece term ZC.

The hypothesis that wide diffusion of affinal terms is caused by avoidance has been noted (Tuite and Schulze 1998). In one view of this, words for avoided inlaws are replaced by euphemisms or foreign words. It is possible that use of a term for 'barrier' instead of 'mother-in-law' began as euphemistic in Worrorran but we have no reliable way of knowing this. The diffusion of this word to Nyulnyulan may also have been motivated by wanting to avoid a more blunt local word for 'mother-in-law' and her brothers and husband, but this is again speculative. In fact there are other words for 'mother-in-law' in Nyulnyulan (e.g. *yalirr) which are not subject to taboo avoidance as far as is recorded.

Rather, it is the key role of such vocabulary in interaction of groups over marriage that may be what leads to the spread of words across languages and ethnic groups. Those involved in making those connections (including the avoided affines) need to be called by terms which are recognised across a broad sociocultural space extending across interethnic alliances. In this case, it may be that both avoidance and the prime role of an in-law in arranging marriage are in play. Level of strictness of avoidance practices around the wife's mother may be in a mutual feedback relationship with the ability to direct operations in marital arrangements. Scheffler (1978: 216) stresses the need among the Karajarri for mother-in-law's husband WF, called kaka ' $\mathrm{MB}^{\prime}$, to be drawn into the central role in negotiations over marriage and as intermediary in gift exchange due to avoidance of the prospective WM.

The term we have followed, ramparr, began as an avoidance term; indeed, in the first phases of diffusion it can mean 'avoidance' itself, together with metaphorical expressions of avoidance. But as the focus of the term changes from mother-in-law to father-in-law, the avoidance character of the relationship also lessens. Nevertheless, the term continues to diffuse along with a different kind of marked relationship of control of marriage. So it is not avoidance itself which causes such widespread diffusion of terms, but the interaction of groups in contracting marriages and remoulding their social arrangements for this.

The origin of the term ramparr is clearly bound up with avoidance between inlaws, primarily a man and his wife's mother and her brother. By the latter part of the journey of this Wanderwort, it still relates to in-laws, but centrally the wife's father, not her mother, and the relationship is no longer one of avoidance. In the east the lamparra father-in-law/son-in-law relationship is a joking relationship 
including hurling of obscenities and horseplay, in some ways the very opposite of the restraint and avoidance behaviour between the ramparr in-laws in the north and west.

There is significantly, though, an area between these two extremes where the change of meaning to 'wife's father' has occurred but the avoidance behaviour also applies in some measure to this father-in-law/son-in-law bond. In Ngarinyin, a Worrorran language, the wife's father (wayingi) is spoken to in 'polite' rambad language known as akaruru (Coate and Elkin 1974). ${ }^{16}$ In some Nyulnyulan languages also, Jawi and Nyikina, the focal meaning of ramparr has shifted to WF, prefiguring the later shift in Ngumpin-Yapa.

\section{Tyam(p)V(ny) 'Mother's Father' > 'Cross-Cousin' $>$ 'Spouse/Sibling-in-Law'}

Unlike the first example ramparr>lamparr, which is confined to a central and western area in northern Australia, the second term tyam $(p) V(n y)$ to be considered here is very widespread in Pama-Nyungan, particularly in the western part of the family (McConvell 2013). Unlike ramparr>lamparr, which was diffused from non-Pama-Nyungan to Pama-Nyungan, $\operatorname{tyam}(p) V(n y)$ was diffused from PamaNyungan into non-Pama-Nyungan in the Kimberley and across into part of the Northern Territory. The primary meaning of tyam $(p) V(n y)$ is 'mother's father' in most of its attestations, but it has secondary meanings of 'cross-cousin', 'spouse' and/or 'sibling-in-law' in many languages, with sometimes a shift to one or other of these secondary meanings, with loss of the original meaning. ${ }^{17}$ There is no great surprise in these polysemies and semantic shifts. MF is often equated with cross-cousin (MBC, FZC) in many Australian Aboriginal kinship systems, following the principle of alternate generation equivalence between kin separated by a generation. Since cross-cousin is the preferred spouse in the Kariera system, which was found in many regions of Australia, this extension and semantic shift is to be expected, and occurs with other terms too.

\footnotetext{
16 Rampat is an alternative form of ramparr in Ngarinyin. Father-in-law is also called lamparru in Ngarinyin. This is a doublet caused by the diffusion of the term northeast from Pama-Nyungan (probably Walmajarri) after lateralisation in Ngumpin-Yapa. The $-u$ is added because the word was borrowed via Bunuba, which adds $-u$ to consonant final roots. Lamparru is also found in Nyikina (eastern Nyulnyulan) and is included in Table 13.2, and its specific meaning is discussed there. Wayingi is glossed 'wife's father' and 'wife's brother' in the dictionary: this is because of Omaha skewing in Ngarinyin and other Worrorran languages whereby the same kinterm can be used for relatives related by patrifiliation (McConvell 2012).

17 There are also apparent cognates in Paman and Mayi languages of North Queensland which have less easily explicable meanings like 'father's sister' and 'wife's father', in the +1 generation instead of the 0 or $+/-2$ generations. For discussion of how this might have occurred, see McConvell (2013). The term for 'mother's father' in this region and more generally in the east of the continent is descended from a different root ${ }^{*}$ gaty $V$.
} 
The spread of the term tyam $(p) V(n y)$ by inheritance in the very large PamaNyungan family is not the central concern here, and is covered in McConvell (2013). Instead the focus is on the diffusion of the term into non-Pama-Nyungan. The aim here is to show that, in accordance with the hypothesis proposed, its affinal function is the main trigger for the diffusion.

This is not immediately obvious, since the primary gloss given for reflexes of the term in a number of non-Pama-Nyungan languages is 'mother's father', apparently consanguineal. It is also possible that the second type of explanation of kinterm diffusion discussed in the introduction - 'filling a gap' in a kinship system when it needs to be augmented - could be an alternative hypothesis. This alternative is discussed and rejected below. ${ }^{18}$

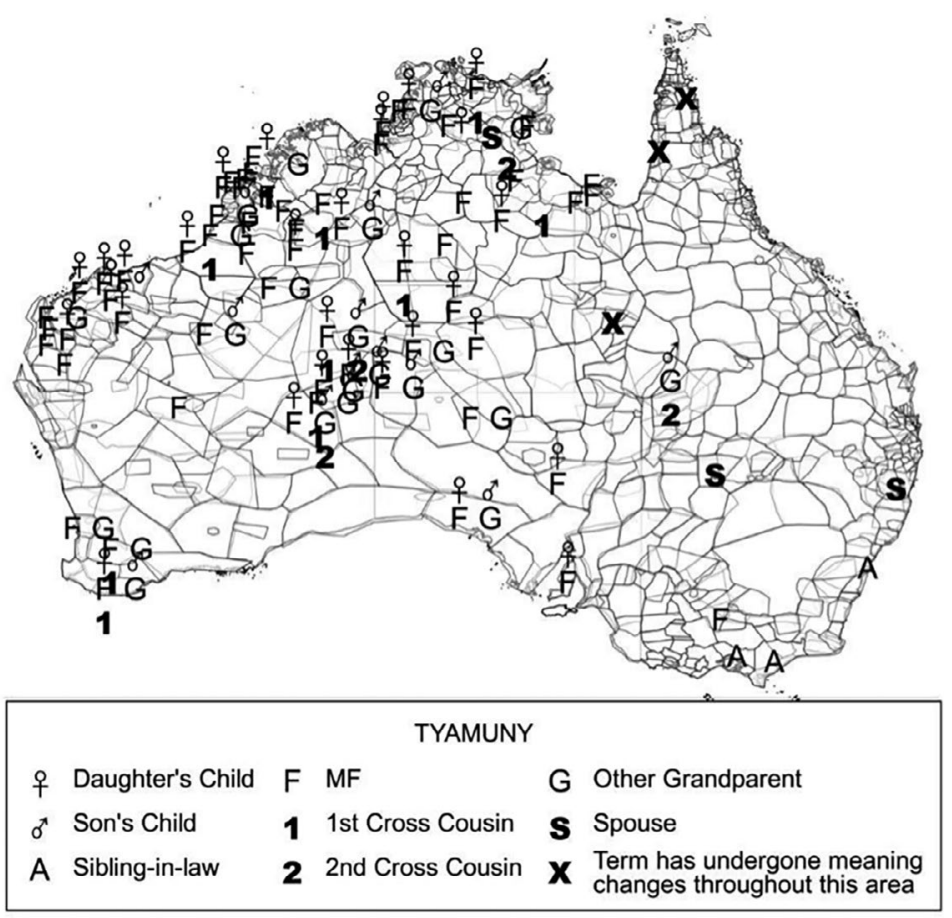

Figure 13.3 TyamVny in non-Pama-Nyungan.

Source: Patrick McConvell.

18 In an earlier attempt to describe and account for the distribution of the MF root tyam(p)V(ny) (McConvell 1997b) I remained agnostic about the origin of this root - whether it diffused into early Pama-Nyungan from non-Pama-Nyungan, or is a proto-Pama-Nyungan root which diffused into some non-Pama-Nyungan families. Additional data and analysis have come down heavily in favour of the second alternative (McConvell 2013). These include adding the term tyampi 'spouse, brother-in-law' found in southeastern Australia to this etymon. Harold Koch (personal communication) has disputed that the southeastern in-law term is connected because it has a different meaning from $\mathrm{MF}$, and has the consonant cluster mp. As argued above the sequence of change MF $>$ cross-cousin $>$ spouse/sibling-in-law is highly credible. A number of the northern forms also have mp or $\mathrm{p}$ instead of $\mathrm{m}$, and ${ }^{*} \mathrm{mp}$ could be plausibly reconstructed in this root. The sound change ${ }^{*} \mathrm{mp}>\mathrm{m}$ is attested in various places in Pama-Nyungan (e.g. Yolngu Matha and the Sydney language), but aligning such a change to the set of languages where $\mathrm{m}$ is found in this root is not yet feasible. 
The spread of the term in non-Pama-Nyungan languages is diffusional. It is found across at least eight adjacent language families in the Kimberley and part of the Northern Territory, going a considerable distance into Arnhem Land. The most northeastern occurrence in the diffusion through non-PamaNyungan found is in Burarra tyamunya ('MF and reciprocal') and the related tyam-ttya ('cross-cousin MBS/MBD; potential spouse') (Glasgow 1985: 95; Hiatt 1967; thanks to Gretel MacDonald for pointing this out to me). This may not be directly adjacent to other languages with related forms, but is not far away. The fact that there is another term for MF in Burarra, mamam (Glasgow 1985: 120) without the cross-cousin/spouse sense, may add to evidence that the tyam form is a loanword based on affinal relationship.

The northern non-Pama-Nyungan families through which tyam $V$ forms are distributed are not thought to be related except in some very distant way to an unclear and very ancient entity usually named 'proto-Australian'. It is virtually impossible to suggest that the form is a joint inheritance from such a protolanguage, because the forms are generally very similar, most of them being tyamVny. Much greater divergence would be expected from a joint inheritance from such a deep proto-language. If the ancestor were proto-Australian or something akin to it, then one would expect such forms to be much more widespread (and probably scattered). The restriction to a particular geographical zone and concentration in it, along what is plausibly a line of spread, point strongly to a diffusion in a relatively recent period.

The tyam Vny + forms with the third consonant ny are the most frequent in nonPama-Nyungan, stretching from western (and proto-) Nyulnyulan tyamuny, through tyaminyi (Bunuban - where augmentation of final consonants by $-i$ is regular - and encroaching into Worrorran), thamany (Kija, southern Jarragan), to western Mirndi in the Barkly Tablelands (tyaminy with suffix -tya or -tyila). To the north tyaminy is also found in the meaning 'spouse' in Ngalakgan, tyamunya in Burarra 'MF/cross-cousin/spouse' (see above) and thamuny in the Daly languages as MF.

tyap $V+$ forms are found in the central part of the distribution. The bare form tyapi is found in Walmajarri (together with forms with $\mathrm{mp}$ in an affinal meaning, e.g. tyampi-rlangu 'husband and wife' (Richards and Hudson 1990: 130)), and tyapiy in Bunuba, alternative to tyaminyi; and a form with the common Pama-Nyungan kinship suffix -tyi (McConvell 2008) in northern Jarragan (Gajirrabeng) and Jaru. The Miriwoong form tyawityi, produced by regular intervocalic lenition $\mathrm{p}>\mathrm{w}$, with the Miriwoong suffix $-n g$ was borrowed into Jaminjungan (western Mirndi, non-Pama-Nyungan) and the eastern Ngumpin languages (Pama-Nyungan). 
All the non-Pama-Nyungan forms are most likely to have spread from the west to the east, and there are forms in the area of Pama-Nyungan in contact with nonPama-Nyungan which could have provided the initial loan source. Tyamu roots without ny are in Nyangumarta (Marrngu subgroup) and other Pama-Nyungan languages to the south and west in the meaning MF, and with a later broader 'grandfather' meaning throughout the Western Desert. Tyami roots without the ny and with the common Pama-Nyungan kinship suffix -rti are in NgumpinYapa (as an alternative to tyapi in Walmajarri and in Warlpiri and Ngardi). These two could have provided the tyamu and tyami roots respectively as loans to Nyulnyulan, and Bunuban, and the tyapi variant to northern Jarragan in the east. In southern Jarragan (Kija) the form is thamany, meaning MF and crosscousin, with $a$ as second vowel, as also in tyamaya, MF and cross-cousin, found in Worrorra and a couple of other western Worrorran languages, but not in southern or eastern Worrorran.

One issue with the picture as presented so far is the preponderance of the ny final consonant in this root in the non-Pama-Nyungan languages but its absence in the putative loan sources, in recent times at least, in northwestern PamaNyungan. It is possible that the earlier forms in northwestern Pama-Nyungan had this final consonant and it was lost after it was borrowed into non-PamaNyungan; or alternatively it was a suffix added to the forms when they entered non-Pama-Nyungan. These questions have not yet been resolved.

${ }^{*}$ tyaminy + ty $V \mathrm{MF}$ is perhaps reconstructable for proto-eastern Mirndi (not in Harvey's 2008 list of proto-forms), but could also be an early loan into the family especially if the -tya/-tyila suffixes reflect the Pama-Nyungan *tyV (McConvell 2008). The western Mirndi form tyawitying is clearly a later loan from Jarragan, probably replacing an earlier tyaminytya or tyaminytyi. The ethnonym Jaminyjung, the major language group of western Mirndi, is part of an ethnonymic paradigm zone (McConvell 2006) with ethnonyms made up of a typical word of the language of the group concerned with a Jarragan suffix -pung/-wung. It is possibly to be analysed as containing the word tyaminyty $V$, the putative earlier pan-Mirndi form of the MF kinship term before it was replaced by tyawityi, thus meaning 'the people who say tyaminyty $V^{\prime} .{ }^{19}$ This is a speculation however, and it begs the interesting question in the context of this chapter, of why this kinship term should be salient enough to form an ethnonym.

This is related to the question of why this kinship term diffused so widely in this zone. Other examples of wide diffusion of kinship terms seem to involve terms with affinal senses and be motivated by changes in marriage systems (McConvell

19 Ethnonyms can contain archaic words pointing to early forms where the meanings have been replaced by other forms in everyday language; see McConvell (2006) for Australian examples. 
2010). In this case for instance, as touched on in the section 'Mother-in-Law > Father-in-Law' above, in Nyulnyulan the term for father-in-law *tyamunyarri (Stokes and McGregor 2003: 62) can be analysed as 'associated with $\mathrm{MF}^{\prime}$ and

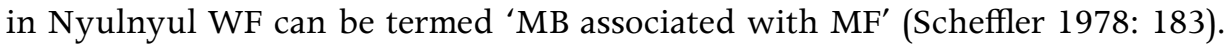
*tyamunyarri is a contraction of such a phrase. Now as we have seen, MF is often extended to mean 'cross-cousin' and 'spouse' in a cross-cousin marriage regime, especially where there is a preference for matrilateral marriage of a man to his MBD, and this extension is common in the non-Pama-Nyungan languages of the Kimberley and east in the Northern Territory.

As for Ngalakgan in the northeast of the diffusion, the affinal meaning of *tyam ( $p$ ) Vny has taken centre stage: tyaminy means 'spouse', not MF. It is a Gunwinyguan language but the root *tyami MF or similar is not reconstructed for this family (Harvey 2003), so it could well be a loanword in Ngalakgan. The form looks related to those far to the west, but the meaning is different. It can be linked via the polysemy chain of $\mathrm{MF}=$ cross-cousin $>$ cross-cousin=spouse, as has been discussed previously, but the current marriage rule is not with a first crosscousin but a MMBDC (an Aranda system) and the term tyaminy designates this kin type as well as spouse. This indicates the fact that once an affinal extension is consolidated, presumably in this case based on cross-cousin marriage, the actual consanguineal/classificatory kin designation can change to the new preferred marriageable kin type. Parallel arguments could be mounted for Burarra to the northwest of Ngalakgan, as already discussed.

This long-distance diffusion of the term for MF is indeed striking and calls for an explanation. While several indications exist of the role of affinal polysemies and connotations in this phenomenon, the explanation is not yet satisfying. Before concluding with a proposal about what might have driven it, let us examine an alternative.

As noted earlier, there are examples of diffusion of grandparent terms which are not directly related to marriage rules and patterns, but seem to be filling in gaps in the kinship terminology system to bring it into line with neighbours. This can be achieved by borrowing the missing terms from those neighbours, as occurred with the Ngumpin-Yapa subgroup as it 'upgraded' from a Kariera or Karadjeri terminology to an Aranda terminology.

Could the same type of situation have been the motivation for a large number of non-Pama-Nyungan language speakers to adopt the new Wanderwort term tyamVny in a chain diffusion? According to the kind of alternative hypothesis being assessed here, this would imply that the pre-existing kinship system among these groups lacked a distinctive term for MF and impelled them to 
borrow one. The most plausible type of system which would lack a distinctive term for MF in Australia is one in which there is a term which is polysemous between MF and FMB (and also perhaps FM) - a Kariera system.

Kariera systems are not known in recent history in the region with the exception of the Daly River. ${ }^{20}$ However, there is evidence from the multiple borrowing of FF terms from different directions that the Ngumpin-Yapa subgroup had, at a previous stage, a Kariera system or a 'Karadjeri' system which did not distinguish between terms for paternal and maternal parallel grandparents FF and MM(B). A similar lacuna might have existed in those non-Pama-Nyungan languages to the north with no distinction between the cross grandparental terms $\mathrm{FM}(\mathrm{B})$ and $\mathrm{MF}$, necessitating the importation of a new MF term. In this case, what occurred was not borrowing from all sides of different terms, but a surge of diffusion of a single MF term (tyamVny) from the south.

It is possible that this revolutionary change was driven by the spread of subsections and the second cousin (MMBDD) marriage associated with it, from its origin area around Katherine and the Lower Daly and Victoria Rivers (McConvell 1985, 1997a). However, part of the spread of the tyam Vny terms was into areas which had no subsections, and either had sections (Nyulnyulan) or no such social categories (part of Worrorran). Most of the languages to which the terms spread in the 'Top End' and Arnhem Land of the Northern Territory have had subsections, at least in recent times, but it is likely that the more peripheral of them received subsections as late as the twentieth century. In some of these peripheral groups the classical type of marriage associated with subsections (MMBDD) did not fully take hold but typically Kariera marriage preferences (cross-cousins) were maintained, possibly in some areas earlier associated with a prior section system, for which we have little direct evidence. A link between the spread of these tyamVny terms and spread of sections or subsections is a possibility but must await further research (see also the previous discussion of the Burarra case where there seems to be evidence against a 'filling a gap' solution or subsection-driven diffusion of tyam(Vny)).

In any case, whether the diffusion was influenced by social categories or not, we cannot totally divorce the notion of 'filling a gap' to produce a more complex kinship terminology from the effect of the introduction of a new marriage system. In the case of the tyam Vny diffusion the key move may have been the introduction of tyamVny with its cross-cousin/spouse sense to signal cross-cousin marriage, but part of the package would have been adding the other meaning of the word 'MF' to the terminology. Further research would be needed to establish whether this was 'filling a gap' in the grandparental terms

20 In the Daly languages the MF term in question was imported but in most cases extended to FMB to adapt to a Kariera system rather than to change it. 
or replacing an earlier term for MF. Most likely the eastern diffusion of tyamVny in the north was related to the ascendancy of the matrilateral cross-cousin as marriage partner, referred to by a term for mother's father. As we have seen in Nyulnyulan in the previous section, the role of the mother's brother, son of MF, is pivotal in controlling marriage, and drives the key position of tyamVny in the affinal terminology.

\section{Conclusions}

This brings us back to the insights of Keen in the book and papers mentioned above (and others). How do kinship terminologies and marriage systems relate to each other? Or are both related to more basic demographic factors? These are some of the fundamental questions of classical anthropology. Here the notion of 'coevolution' is critically evaluated and applied to the relationship of kinship and marriage in some actual cases as they develop through time. Diachronic analysis of the change in kinship systems in Aboriginal Australia over the short term is sometimes possible from historical documents, but over the longer term the work of comparative historical linguistics yields more evidence about the past state of kinship systems, and sometimes of at least ideal marriage patterns, for instance in the polysemies of affinal and consanguineal terms in a range of languages. The actual marriage patterns over time are not always readily available or analysed, but some genealogical databases do exist from which we can derive such diachronic data. Data on correlated change (or absence of correlation in change) can be much more valuable for theory in this area than correlations of synchronic snapshots.

With this perspective in mind, this chapter has been able to look at two diffusions of kin terms in northern Australia. The first, concerning ramparr/ lamparr, was all about marriage and affinity from the start, bound up with concepts of in-law avoidance. As it moved through three language families first west, then east, it changed meaning from mother-in-law to father-in-law, and the dominant behaviours shifted from avoidance to joking. The borrowing of the term was intimately linked to its relationship to changes in authority structures in marriage, which put more control in the hands of the father-in-law. Such affinal terms and their implications are the elements which are most likely to be loanwords, as these are key concepts in a field of law and custom which crosses ethnic and language boundaries. In this interethnic field changes occur in marriage practice and these can spread concepts and terminology often quite rapidly. 
The second example discussed is a set of terms descended from ${ }^{*} \operatorname{tyam}(p) i$ 'mother's father', reflexes of which are found across a wide area of Australia. This is a Pama-Nyungan proto-form and most of its occurrences are inheritances in Pama-Nyungan languages. However in northern Australia many related forms are found in a quite large area of several non-Pama-Nyungan languages adjacent to the northern boundary of Pama-Nyungan. These are clearly part of a pulse of loanwords from northern Pama-Nyungan. Unlike the in-law terms of the previous example, this looks at first blush like a consanguineal term, contradicting the hypothesis proposed that long-distance kinship loanwords are affinal. However there are very common equations (between MF and crosscousin, and cross-cousin and spouse/sibling-in-law) which lead to this MF term having important secondary meanings. In this way, this example too supports the hypothesis that the motivations for kinship Wanderwörter to wander are primarily because of their role in marriage over wide areas of multiple ethnicity and language.

\section{References}

Aklif, G. 1999. Ardiyooloon Bardi Ngaanka: One Arm Point Bardi Dictionary. Halls Creek: Kimberley Language Resource Centre.

Bowern, C. 2007. On eels, dolphins, and echidnas: Nyulnyulan prehistory through the reconstruction of flora and fauna. In A. Nussbaum (ed.), Verba Docenti: Studies in Historical and Indo-European Linguistics Presented to J.H. Jasanoff by Students, Colleagues, and Friends, pp. 39-52. Ann Arbor: Beech Stave Press.

Clackson, J. 2007. Indo-European Linguistics: An Introduction. Cambridge: Cambridge University Press.

Clendon, M. 2000. A Provisional Worrorra Dictionary. Halls Creek: Kimberley Language Resource Centre.

Clendon, M. 2014. Worrorra: A Language of the North Kimberley Coast. Adelaide: University of Adelaide Press.

Coate, H. and A.P. Elkin. 1974. Ngarinjin-English Dictionary. Sydney: Oceania Linguistic Monographs.

Denham, W. 2013. Beyond Fictions of Closure in Australian Aboriginal Kinship. Mathematical Anthropology and Cultural Theory 5(1): 1-90. 
Dixon, R.M.W. and A. Aikhenvald. 1999. Introduction. In R. Dixon and A. Aikhenvald (eds), The Amazonian Languages, pp. 1-22. Cambridge: Cambridge University Press.

Dousset, L., R. Hendery, C. Bowern, H. Koch and P. McConvell. 2010. Developing a database for Australian Indigenous kinship terminology: the AustKin project. Australian Aboriginal Studies 1: 43-56.

Dziebel, G. 2012. Indo-European and North Caucasian: Linguistic Typology, Kinship Terms and Autosomal Genetics. kinshipstudies.org/2012/07/07/ indo-european-and-north-caucasian-linguistic-typology-kinship-termsand-autosomal-genetics/.

Elkin, A.P. 1928. Nyulnyul Social Organisation. MS.

Elkin, A.P. 1932. Social organization in the Kimberley Division, north-western Australia. Oceania 2(3): 296-333.

Evans, N. 1992. Multiple semiotic systems, hyperpolysemy, and the reconstruction of semantic change in Australian languages. In G. Kellermann and M. Morrissey (eds), Diachrony Within Synchrony: Language, History and Cognition, pp. 475-508. Bern: Peter Lang Publishing.

Evans, N. and D. Wilkins. 2000. In the mind's ear: the semantic extensions of perception verbs in Australian languages. Language 76(3): 546-92.

Glasgow, D. and K. Glasgow. 1985. Burarra to English Bilingual Dictionary. Darwin: SIL/AAB.

Harvey, M. 2003. An initial reconstruction of Proto-Gunwinyguan phonology. In N. Evans (ed.), The Non-Pama-Nyungan Languages of Northern Australia: Comparative Studies of the Continent's Most Linguistically Complex Region, pp. 205-68. Canberra: Pacific Linguistics.

Harvey, M. 2008. Proto Mirndi: A Discontinuous Language Family in Northern Australia. Canberra: Pacific Linguistics.

Haynie, H., C. Bowern, P. Epps, J. Hill and P. McConvell. 2014. Wanderwörter in languages of the Americas and Australia. Ampersand 1(1): 1-16.

Heath, J. 1981. Basic Materials in Mara: Grammar, Tests, Dictionary. Canberra: Pacific Linguistics.

Hernandez, T. 1941. Social organization of the Drysdale River tribes. Oceania 11(3): $211-32$.

Hiatt, L. 1967. Unpublished field notes, held at AIATSIS. 
Keen, I. 1982. How some Murngin men marry ten wives: the marital implications of matrilateral cross-cousin structures. Man 17(4): 620-42.

Keen, I. 2004. Aboriginal Economy and Society: Australia at the Threshold of Colonisation. South Melbourne: Oxford University Press.

Keen, I. 2013a. The legacy of Radcliffe-Brown's typology of Australian Aboriginal kinship systems. Structure and Dynamics 6(1): 1-31.

Keen, I. 2013b. The evolution of the Yolngu and Ngarinyin kinship terminologies: models of cumulative transformations. In P. McConvell, I. Keen and R. Hendery (eds), Kinship Systems: Change and Reconstruction, pp. 132-62. Salt Lake City: University of Utah Press.

Lewis, D. 2007. The Murranji Track: Ghost Road of the Drovers. Rockhampton: Central Queensland University Press.

Marck, J., P. Hage, K. Bostoen, and J.K. Muzenga. 2011. Kin terms in the East Bantu proto languages: initial findings. In B. Milicic and D. Jones (eds), Kinship, Language, and Prehistory: Per Hage and the Renaissance in Kinship Studies. Salt Lake City: University of Utah Press.

Matasović, R. 2012. Areal typology of proto-Indo-European: the case for Caucasian connections. Transactions of the Philological Society 110(2): 283-310.

Matras, Y. 2009. Language Contact. Cambridge: Cambridge University Press.

McConnel, U. 1950. Junior Marriage Systems: Comparative Survey. Oceania 21(2): 107-45.

McConvell, P. 1985. The origin of subsections in northern Australia. Oceania. 56: $1-33$.

McConvell, P. 1997a. Long lost relations: Pama-Nyungan and northern kinship. In P. McConvell and N. Evans (eds), Archaeology and Linguistics: Aboriginal Australia in Global Perspective, pp. 207-36. Melbourne: Oxford University Press.

McConvell, P. 1997b. The semantic shift between 'fish' and 'meat' and the prehistory of Pama-Nyungan. In M. Walsh and D. Tryon (eds), Boundary Rider: Essays in Honour of G.N. O'Grady, pp. 303-25. Canberra: Pacific Linguistics.

McConvell, P. 2006. Shibbolethnonyms, ex-exonyms and eco-ethnonyms in Aboriginal Australia: the pragmatics of onymization and archaism. Onoma 41: $185-214$. 
McConvell, P. 2008. Grandaddy morphs: the importance of suffixes in reconstructing Pama-Nyungan kinship. In B. Evans and C. Bowern (eds), Morphology and Language History: In Honour of Harold Koch, pp. 313-28. Amsterdam: Benjamins.

McConvell, P. 2009. Loanwords in Gurindji, a Pama-Nyungan language of Australia. In M. Haspelmath and U. Tadmor (eds), Loanwords in the World's Languages: A Comparative Handbook, pp. 790-822. Berlin: de Gruyter.

McConvell, P. 2010. The archaeolinguistics of migration. In J. Lucassen, L. Lucassen and P. Manning (eds), Migration History In World History: Multidisciplinary Approaches, pp.155-88. Leiden: Brill.

McConvell, P. 2013 Proto-Pama-Nyungan kinship and the AustKin project: reconstructing terms for proto-mother's father and their transformations. In P. McConvell, I. Keen and R. Hendery (eds), Kinship Systems: Change and Reconstruction, pp. 192-216. Salt Lake City: University of Utah Press.

McConvell, P. 2012. Omaha skewing in Australia: overlays, dynamism, and change. In T.R. Trautmann and P.M. Whiteley (eds), Crow-Omaha: New Light on a Classic Problem of Kinship Analysis, pp. 243-60. Tucson: University of Arizona Press.

McConvell, P. and I. Keen. 2011. The transition from Kariera to an asymmetrical system: Cape York Peninsula to north-east Arnhem Land. In D. Jones and B. Milicic (eds), Kinship, Language, and Prehistory: Per Hage and the Renaissance in Kinship Studies, pp. 99-132. Salt Lake City: University of Utah Press.

McConvell, P. and M. Laughren. 2004. The Ngumpin-Yapa subgroup. In C. Bowern and H. Koch (eds), Australian Languages: Classification and the Comparative Method, pp. 151-77. Amsterdam: John Benjamins Publishing Company.

McConvell, P. and M. Ponsonnet. 2013. Results and prospects in the study of semantic change: a review of From Polysemy to Semantic Change (2008). Journal of Language Contact 6 (2013):180-96.

McConvell, P., T. Saunders and S. Spronck. 2014. Linguistic prehistory of the Australian boab. In L. Gawne and J. Vaughn (eds), Selected Papers from the 44th Conference of the Australian Linguistic Society, 2013. Melbourne: University of Melbourne. 
McConvell, P. and M. Smith. 2003. Millers and mullers: the archaeolinguistic stratigraphy of seed-grinding in Central Australia. In H. Andersen (ed.), Language Contacts in Prehistory: Studies in Stratigraphy, pp. 177-200. Amsterdam: Benjamins.

McGregor, W. and A. Rumsey. 2009. Worrorran Revisited: The Case for Genetic Relations among Languages of the Northern Kimberley Region Western Australia. Canberra: Pacific Linguistics.

Meakins, F., P. McConvell, E. Charola, N. McNair, H. McNair, L. Campbell and G. Wightman (compilers). 2013. Gurindji to English Dictionary. Batchelor: Batchelor Press.

Rangan, H., K. Bell, D. Baum, R. Fowler, P. McConvell, T. Saunders, S. Spronck, C. Kull and D. Murphy. 2015. New genetic and linguistic analyses show ancient human influence on baobab evolution and distribution in Australia. PLOS ONE 10(4): e0119758. doi:10.1371/journal.pone.0119758.

Richards, E. and J. Hudson. 1990. Walmajarri-English Dictionary. Darwin: Summer Institute of Linguistics.

Scheffler, H. 1978. Australian Kin Classification. Cambridge: Cambridge University Press.

Stokes, B. and W. McGregor. 2003. Classification and sub-classification of the Nyulnyulan Languages. In N. Evans (ed.), The Non-Pama-Nyungan Languages of Northern Australia: Comparative Studies of the Continent's Most Linguistically Complex Region, pp. 29-74. Canberra: Pacific Linguistics.

Tuite, K. and W. Schulze. 1998. A case of taboo-motivated lexical replacement in the indigenous languages of the Caucasus. Anthropological Linguistics 40(3): 363-83. 
This text is taken from Strings of Connectedness: Essays in Honour of Ian Keen, edited by Peter Toner, published 2015 by ANU Press, The Australian National University, Canberra, Australia. 